\title{
Dialogue
}

"Vot Long Stret Man": Personality, Policy, and the Election of Ralph Regenvanu, Vanuatu 2008

BENEDICTA ROUSSEAU

"We Were Still Papuans": A 2006 Interview with Epeli Hau'ofa NICHOLAS THOMAS

(C) 2012 by University of Hawai'i Press 


\section{"Vot Long Stret Man": Personality, Policy, and the Election of Ralph \\ Regenvanu, Vanuatu 2008}

Benedicta Rousseau

On 5 September 2008, about one thousand people gathered at the Saralana stage in Port Vila, the capital of Vanuatu, for a victory party to celebrate the successful independent candidature of Ralph Regenvanu in the national elections three days earlier. The soundtrack for the evening came from the recently formed hip-hop group Genesis-named for their devotion to the Bible, rather than Phil Collins-who the previous day had hastily recorded their unsolicited song of support, "Inaf!" Inspired by Ralph's campaign slogan, their lyrics captured a number of the key campaign themes: "Enough is enough/we've got to make a change now"; "They want to talk a lot/not act a lot"; "Vanuatu! It's time to detox"; "For 28 years we were driven by corruption/the national budget was spent on personal satisfaction"; "Ralph Regenvanu: he came, he saw, he conquered." Genesis's spontaneous celebration of Ralph and his perceived potential to bring about change also demonstrated his success in gaining the support of the "youth demographic"-a section of Port Vila's population that has been typified as politically apathetic and often troublesome. Fittingly enough, too, it has been through his involvement in music and his advocacy for young people that Ralph has gained the trust of that particular group. ${ }^{1}$

But young people alone do not account for the level of support for Ralph shown in the Port Vila electoral results. The constituency of about I 8,000 registered voters elects six members of Parliament to represent a population of approximately 40,000 . In a field of forty-eight candidates, Ralph gained I,710 votes, 624 more than his closest rival. This set a new record for the highest number of votes gained by a member of Parliament in Vanuatu and represents around I I percent of the total votes cast in the

The Contemporary Pacific, Volume 24, Number I, 98-II 8

(C) 2012 by University of Hawai' $i$ Press 
electorate. While the numbers may seem rather small, it is important to emphasize that this was considered a landslide by supporters as well as others. On election night, as the results came in from each polling booth, Ralph himself described it as "embarrassingly good ... it was what we thought might happen in our wildest dreams."

The title of this essay-"Vot long stret man"-comes from a piece of graffiti found painted on a Port Vila street a couple of days before the election. This phrase or injunction translates from Bislama as "Vote for the right person" and points to two of the questions that this research addresses: How do ni-Vanuatu decide who the "right person" is, and why did so many decide that Ralph was the "stret man"? I start by providing some contextualization of Ralph's candidature and campaign before moving on to explore some of the analytical and ethnographic avenues that help to answer these two questions.

\section{Who Is Ralph Regenvanu?}

Until the end of 2006, Ralph was director of the Vanuatu Cultural Centre, an institution that encompasses the National Museum, National Archives, National Library, National Film and Sound Archives, Women's Culture Project, Vanuatu Cultural and Historical Sites Survey, Young People's Project, and Oral Traditions Project, among others. It is overseen by the Vanuatu National Cultural Council, of which Ralph remained director until late 20I0. The council also administers access to Vanuatu by foreign researchers, particularly anthropologists, linguists, and archaeologists. Ralph is the son of two Presbyterian pastors, Dorothy and Sethy. Sethy is from the island of Uripiv, just off the coast of Malakula, while Dorothy is originally from Australia. Sethy was a member of the first generation of indigenous parliamentarians in Vanuatu, rising to the position of deputy prime minister in the early I 990 os before retiring from politics. After attending school in Vanuatu and Australia, Ralph completed an honors degree in anthropology and development studies at the Australian National University. On his return to Vanuatu he started work with the cultural and historical sites survey at the cultural center and moved on to become curator before taking up the director's position in 1995. This coincided with the development of the Vanuatu Cultural Research Policy and the lifting of an eleven-year moratorium on foreign social sciences research in the country. As a result, Ralph has been a primary liaison and gatekeeper for most anthropologists researching in Vanuatu (myself included) over the past 
fifteen years. In addition, he has been active internationally in the promotion of indigenous management of cultural resources, appearing regularly at conferences around the world and representing Vanuatu and the Pacific in a variety of UNESCO forums. Following his resignation from the cultural center, Ralph went back to school to complete a law degree at the University of the South Pacific. On I7 April 2008 he officially announced his intention to run as an independent candidate in the national elections. ${ }^{2}$

When this decision was publicized in an article in Vanuatu's Daily Post newspaper, it became one of the most read and most commented on articles on their website. As of January 2009, there had been eighty-nine comments on the article, overwhelmingly giving support to Ralph and also using the forum to engage in a broader discussion of Vanuatu politics. ${ }^{3}$ The popularity of this article and the level of engagement via the Internet points to a further demographic that ensured Ralph's victory-the educated, middle-class ni-Vanuatu, based predominantly in Port Vila. This Internet-savvy group (who are also those who can afford Internet access or have it through their work) were further courted by Ralph through his website, ralphregenvanu.org. His was the first electoral campaign in Vanuatu to make use of the Internet-both an e-mail list for supporters and the website as a forum for dissemination of information regarding campaign events. In helping build a strong community of support and mitigating the isolation that may come with being an independent candidate, these electronic communication tools could stand in for more established practices of party membership.

With these innovations in mind, and given the level of support that Ralph eventually gained in the election, the question emerges: was this an exceptional or anomalous campaign? This is certainly how it has been portrayed in some quarters, often with the aim of dismissing Ralph's potential impact. In a speech soon after the elections, for instance, Michael Morgan, then director of the International Projects Unit of the Australian Labor Party (ALP), summed up such an attitude:

This is a well worn path in politics around the world-charismatic young candidate seeks to challenge the establishment on a platform of change.

The reality is much more complex, particularly when candidates seek to push through their agenda items in the rough and tumble of legislative politics....

Irrespective of the virtue of the campaign and the groundswell of popular opinion which delivered Regenvanu victory, to effect change in politics MPS have to engage with the political process. (Morgan 2008, 9) 
A similar tone was taken by experienced commentator on Vanuatu politics, Howard Van Trease: “While Regenvanu's success in Port Vila appeared to signal the possible emergence of a new reform-oriented younger generation, political newcomers in Vanuatu find themselves quickly obliged to engage in the same kind of wheeling and dealing as their predecessors" $(2009,5){ }^{4}$ These comments raise a number of questions: What are "politics" and the "political process" in the context of Vanuatu? Should Ralph indeed be described as a "political newcomer"? If he can be seen as a virtuous but most probably ineffectual exception, how then did he come to be seen as a legitimate choice for voters?

\section{The Problems of “Melanesian-style” Politics}

Writing back in 1982, Ron May, a long-standing analyst of contemporary Melanesian politics, commented on the recurrent use of the term "style" in descriptions of political activity in the region (May I982, 639). More than twenty years later, this term continues to be used (see, eg, Rich 2006, 2; Morgan 2005, 3), suggesting agreement among commentators that there is something distinctive and potentially definable about the way in which the indigenous populations engage in parliamentary politics. However, the context of the reproduction of this notion has changed over time. Earlier examples examined this "style" from the perspective of ethnographically and historically informed comparative politics, concentrating on the specific manifestation and interpretation of independence and postcolonial politics in the new Melanesian nations. More recent work, however, has moved in two related directions. The first uses seemingly objective criteria to portray Melanesia as inherently/stylistically problematic and deficient in the necessary traits of contemporary democratic politics. Benjamin Reilly, for example, has declared that "these are troubled times for democracy in the South Pacific" (2000, 26I), making a direct equation between "ethnic diversity" and "variation in political stability" to explain "state failure" in Melanesia's "highly fragmented societies" (2004, 479, 482). Roland Rich used political scientist Larry Diamond's assertion that "political parties remain an indispensable institutional framework for representation and governance in a democracy" (Diamond 1999, 96, quoted in Rich 2006, I) as the justification for an edited volume addressing "the problem of Pacific Island political parties," choosing to question the political "style" of a region, rather than Diamond's premise (Rich 2006).

In tandem with the measurement of Melanesian political performance 
against such "universal" criteria has been an increase in what I term culturalist explanations for supposed political idiosyncrasy in the area. Such an approach emphasizes the legacy of "tradition" and tenacity of indigenous practice, even in the face of decolonization and democratic reform. Abby McLeod, for example, outlined "models of leadership" in the Pacific, arguing for the permeation of state institutions by "indigenous leaders and notions of leadership" $(2008,8)$. Her discussion paper addresses "providers of overseas development assistance to the region [who] have become increasingly concerned with the ways in which social order . . . is maintained" (McLeod 2008, I), suggesting that the premise of "a problem" in the Pacific again forms the starting point for academic analysis. This comes through clearly in her reminder that even those who take on contemporary, nonindigenous leadership roles may still be held ransom by culture: "In the village context, the person who fails to support their wantok faces a host of possible sanctions. ... Fear of these sanctions does not disappear upon assuming office in either politics or the public service, rendering many decisions made in institutional settings captive to the [wantok] system" (McLeod 2008, 8). In a similar vein, Morgan emphasized the importance of understanding "culture" in determining which areas of Melanesian parliamentary political activity may be amenable to reform (2005). As he concluded, "expecting institutional strengthening projects to facilitate the overhaul of the Melanesian polities in their totality, without regard for the cultural influences on parliamentary politics, is blindly ethnocentric" (Morgan 2005, I3).

The emphasis here on the problematic role of "culture" in relation to supposedly universal traits of parliamentary political practice tacitly delineates an imagined "acultural politics" that has not been attained in Melanesia. Politics is rendered as ideally and potentially a "space of no culture" (Gershon and Taylor 2008). This shift in approach coincides with the intertwining of academic interest in contemporary politics in Melanesia and particularly Australia's redefinitions of its role and responsibilities in the region. While Vanuatu appears more as an occasional honorary member of the "arc of instability" than as a committed protagonist, the "problem" of Melanesian-style politics has been extrapolated to it as well. To summarize, key tropes of this discourse encompass an emphasis on personality over policy; a tendency toward consensus and bloc voting; a desire for short-term gain over a long-term commitment to a vision for the nation; and the use of patronage and exploitation of kinship ties by "big men" in their search for support. 
As Ilana Gershon and Janelle Taylor have argued, the particular credence given to a concept of culture in "spaces of no culture" is historically specific, and due attention must be given to the circumstances in which "culture" is seen as relevant to our understanding of people's behavior in relation to particular institutional settings: "People are not consistently framed as culture bearers, and it is crucial to understand why and how the culture category becomes an issue at a particular moment. Focusing on temporal processes allows analysts to unravel when and how institutions construct the cultural and the acultural and how this form of classification instantiates power inequalities" (Gershon and Taylor 2008, 420-42I). The rise in culturalist analyses of Melanesian politics is indeed tied to broader geopolitical shifts in the region. While the discourse of "instability" and "state failure" often dominates discussion of Melanesian politics and informs more overtly interventionist policies (see Fry and Kabutaulaka 2008), the analyses that I highlight here provide the rationale for "softer" interventions, such as the Political Party Development and Parliamentary Strengthening initiatives undertaken by the Canberra-based Centre for Democratic Institutions as well as further examples that I discuss later in this article. I suggest that a key effect of such an approach is to dehistoricize our understanding of political activity. Reflecting in particular on politics in Vanuatu, I would argue that the above summation of "style" ignores both the historical context of political activity in the country and indigenous measures of appropriate leadership, while also presenting a limited view of what "national policy" should look like. In particular, the inherently negative portrayal of "big men" and their manipulated kinbased group of supporters simplifies the networks that have been necessary parts of gaining political power in Vanuatu and overemphasizes kinship as the primary mode of contemporary identification. I do not suggest that kin is not a common basis for measures of relatedness in Vanuatu. Rather, it is essential to recognize that other affiliations play a key role in most people's electoral decision making. While overlap may occur at times, church, island of origin, place of residence, place of employment, age, and increasingly class are all sources of affiliation that can crosscut kinship. This is particularly true too in the context of Port Vila. Mobility of people-and, increasingly, mobility of information through radio, television, e-mail, and particularly mobile phones-also mitigates the perpetuation of place-centered political support.

And these are not just novel phenomena. The history of party political activity in Vanuatu indicates these trends: Prior to independence, the 
Nagriamel movement, led by Jimmy Stevens, garnered support in association with the Churches of Christ (Morgan 2003); the message of the Vanua'aku Pati, which ultimately led the first eight years of independent government, spread through a network encompassing Presbyterian and Anglican churches, the public service, and commissars acting as messengers to area and village subcommittees; the Union des Communautes des Nouvelles Hebrides party, backed primarily by French business interests, courted taxi drivers in Port Vila as valuable communicators of their procondominium platform (Van Trease 1995). While voting decisions in many places may have fallen along kinship or village lines, it is important to see this as a result, rather than a given, and to examine the network and positioning of the candidate that brings about this result. Of relevance here too is the transnational circulation of ideas-now often through nongovernmental organizations, but also, as in the era before independence, through regional educational institutions such as the University of the South Pacific, the University of Papua New Guinea, and the Australian National University. To isolate political style geographically is too frequently to perpetuate a view of indigenous people as frozen in time, culture, and location and to ignore the connections that exist within and outside the country.

\section{Building Support: The Context of Ralph's Candidature}

These points are all relevant to Ralph's campaign. His win should not be seen as a fortuitous glitch or as a rapid mobilization of disparate constituencies. Rather, it must be situated within the context of civil society politics in Vanuatu over the past few years. Ralph's campaign platform stems in large part from a group of objectives that have been pursued under the banner of the National Strategy for Self-Reliance and Sustainability, originating in a national summit on the topic in 2005 . The proposals developed at the national summit can be seen as an explicit challenge to the direction that national politics had been moving in since the introduction of the Asian Development Bank-sponsored Comprehensive Reform Programme (CRP) in the mid-I990s. Oriented around a valorization of indigenous resources and knowledge, the national summit proposals emphasized a need for less reliance on imports-food in particular-and on the cash economy. Also emphasized was the urgent need for tightened control over the alienation of land through the sale of leases, predominantly to expatriates, a practice that has reached concerning levels on Efate in particular. 
This resulted in the National Land Summit, held in Port Vila in September 2006. The primary aim of the activities that have emerged through the self-reliance and sustainability program has been to put pressure on the national government-members of Parliament, ministers, and civil servants-to shift their priorities away from the CRP agenda and to develop policies that recognize the continued dependence of the majority of niVanuatu on subsistence food production and the continued relevance of indigenous knowledge and practices in everyday life. As such, the strategy was framed as a vision for national progress away from an externally determined-and often internally supported — view of development.

Initially the strategy seemed to gain credence among bureaucrats and some politicians, most prominently Prime Minister Ham Lini. The year 2007 was declared the Year of the Kastom Economy, as was 2008. However, the impetus seemed to falter, especially around the issue of land, and the lack of progress in terms of government recognition of the suggested policy directions formed the basis for Ralph's decision to stand for Parliament. Parallel to this, the alliances formed in the development of the self-reliance and sustainability platform contributed much of the support infrastructure that ultimately ensured his victory. As mentioned, the Vanuatu Cultural Centre played a key role in the promotion of self-reliance, alongside the Malvatumauri (National Council of Chiefs) and the Credit Union. Cultural center staff were predominantly active supporters and campaigners for Ralph, and the networks established through the work of the center's Young People's Project over the past ten years lent further credibility and support to the campaign in communities across Port Vila. In addition, self-reliance was adopted as an outcome of vanwods (the Vanuatu Women's Development Scheme), to be realized through their micro-finance programs. This resulted in women who were part of the scheme committing their votes to Ralph. The recent proposal for a tunaprocessing plant on the outskirts of Port Vila had led to the formation of Residents Against Processing Tuna in Port Vila (RAPT), another group that supported Ralph's candidacy. His activities in the National Workers' Union gained additional supporters, although this was mitigated by the ultimately unsuccessful campaign of Ephraim Kalsakau, head of the union and candidate of the Labor Party.

My point here is twofold. I want to emphasize the continued relevance of often institutionally based networks (other than established political parties) to the accrual of support in election campaigns. In addition, though, I present this context in order to question the idea that personality 
trumps policy in Vanuatu politics, as suggested in Morgan's 2008 speech. He described the "problem"- "What is yet to develop fully [in Vanuatu] is the national policy debate. ... A notable absence in past elections has been a national policy debate where parties campaign on issues, not just personality, ethnicity and kin" (Morgan 2008, 7-8)-but did not articulate what such a debate might or should look like. In the following section I provide material that suggests that campaigning does indeed include elements of policy debate, and I contrast this with an ALP-funded initiative that sought to redress the problematic "lack" of such debate.

\section{What Does Policy Look Like?}

In terms of the 2008 election campaigning in Port Vila, the suggestion that policy is predominantly absent does not entirely stack up. Campaigning often involved meetings in suburbs, particularly those with which the candidate had some prior connection. These smaller-scale meetings were supplemented by larger gatherings in the public seafront area in the center of town, and a series of lunchtime speeches by candidates in the market house. These speeches generally attracted crowds of one to two hundred, some dividing their attention between the speaker and their shopping. Questioning of candidates at these public meetings was common practice, even for some of the old-guard politicians, who are often typified as most lacking in accountability and trading on personality. Topics covered tended to concentrate on domestic issues-increasing the minimum wage, ensuring that the country's recent and unusual economic growth would continue, eliminating school fees-but also included foreign policy matters and inquiries regarding candidates' positioning in relation to accepting aid. Responses may not always have been of a high caliber. A former minister of finance, for instance, rejected an increase in the minimum wage on the grounds that this would result simply in employees being "replaced by machines." Yet several interviewees cited a willingness to accept questions as one of the prerequisites to being considered an appropriate candidate, ${ }^{5}$ indicating both the desire for debate and an expectation that candidates would be prepared to respond. Beyond public speeches and questioning, posters and leaflets were the most common way in which candidate and party platforms were put forward. Posters were put up throughout the city center and on storefronts throughout the Port Vila suburbs. These often contained detailed policy statements and diagrammatic structures of how the government might be reformed, and people could frequently be 
observed perusing them in some depth. The necessarily public engagement with these posters also resulted in discussion among those reading them. Fair play, respect, and free access to information were emphasized in conversations about the campaign, as well as in the media through reminders that candidate posters should not be covered over or torn down. ${ }^{6}$

Such evidence indicates that policy debate is not absent from the activities surrounding election campaigning in Port Vila and, combined with the example of the role that the Self-Reliance and Sustainability project played in Ralph's campaign, also suggests the need to trace the ways in which issues move into and through varying stages of institutionalization. How do "issues" become "policies"? Who defines them as such? This represents a cumulative perspective on political debate and policy formation, rather than reiterating and attempting to rectify its absence only at election time.

The latter was the approach taken in 2008 by the Australian Labor Party in association with the Port Vila-based Pacific Institute for Public Policy (PIPP). These two organizations collaborated on the production of a booklet outlining the structure, support base, "key people," and policy platforms of all the major parties in Vanuatu. The booklet, released a couple of weeks prior to the election, represents something of a triumph of form over substance. Unlike previous publications such as Howard Van Trease's edited Melanesian Politics: Stael Blong Vanuatu (1995), the ALPsponsored booklet did not aim to give voice to the political parties, but rather sought to valorize the concept of the political party and to define its parameters through comparative presentation. In discussing the booklet, one of those involved in its production mentioned to me that several of the parties had had no immediately available policy for publication when first approached. Instead, they took the opportunity to look at how other parties had set out their policies, and then provided what were in some cases quite similar documents for inclusion in the booklet. This was mentioned as an aside rather than as a problem; it seemed that the task had been accomplished through the ultimate provision of "a document." What is relevant, though, is that the similarity among the platforms presented in the booklet has now been used as further evidence of the "not fully developed" status of national policy in Vanuatu politics. I would not argue that all parties or independent candidates in the election had a substantial and clearly expressed national policy vision. However, the booklet seems an unfair measure of the progress or otherwise of policy debate in the country. Issues surrounding literacy, culturally and financially appropriate 
means of transmitting knowledge, and the mismatch between "official" and local idiom when it comes to the concepts of democracy (here I refer to ideas such as "governance," "transparency," "civil society") can make it hard for political debate and coherence of vision to be recognized as such when held up to externally defined measures.

While Morgan's speech did note that Ralph's campaign suggests that "issues" can contribute to victory, his presentation of Ralph as singular in relation to established parties in particular gives only a partial picture of how campaigning is conducted. As with the example of the ALP/PIPP booklet, such commentary fetishizes the forms of democracy: "political parties," "the political process," "policy," “candidates," and "voters" are idealized as types, more or less successfully embodied by ni-Vanuatu. This tallies with a broadly articulated concern from social theorists "that democracy throughout much of the world has increasingly been reduced from the substantive to the procedural, from social movement to electoral process" (Comaroff and Comaroff I997, I26). I suggest that the anthropological study of elections can counteract this shift. Commenting on the relative scarcity of such studies, David Gellner argued that "anthropologists, as specialists in the local and small scale, can contribute a radically different perspective from other social scientists" to our understanding of electoral activity (2009, II 5). This point is amply demonstrated by Mukulika Banerjee's study of election day in her long-term fieldsite in West Bengal (2007). As she concluded, "it finally became clear to meafter prolonged work in the village-that all actors in the 'macro-politics' of election day were conducting themselves in ways that were inextricably linked to the previous months and years of the 'micro-politics' of the village. In retrospect, election day was when the complexity of the village's social life was distilled into moments of structure and clarity, when diffuse tensions and loyalties were made unusually manifest. So the election offered potentially powerful snap shots that light up a longer and more diffuse 'thick description'" (Banerjee 2007, I 56I).

What these authors point to is the need to contextualize, rather than typify, the actors and actions involved in any election. In presenting the background to Ralph's campaign, I have attempted to open up the definition of the "political process" that Regenvanu and, by extension, his supporters were portrayed as having yet to engage in. And the same is necessary in considering contemporary political leadership more broadly: the parliamentary candidate cannot be considered an isolated or generic "type." Instead, as I argued for with policy development, we need to understand 
leadership as a cumulative property of a person, often gained by various transitions through different institutional settings and affiliations. Bringing this greater analytical depth to considerations of parliamentary candidates in Vanuatu can help us understand the processes involved in the recognition of appropriate leadership: how candidates attempt to manifest it and, importantly, why their legitimacy may be accepted or rejected by voters at election time-in short, the questions I raised around the injunction to "vot long stret man." In conclusion, I consider aspects of the "public culture" of Ralph's campaign and the 2008 election in general to demonstrate the ways in which ethnographic investigation illuminates the particularities of Vanuatu political activity without reducing it to an ahistorical and problematic expression of "culture."

\section{Ralph's Campaign in Action}

Ralph's campaign was qualitatively different from those of other candidates in Port Vila. Yet, what is interesting here is that he did not necessarily present a "new style of leadership," nor did he embody traits of legitimate indigenous leadership in a fully successful manner. But given his success with voters, his self-presentation provides an interesting case study of the parameters of leadership in contemporary Vanuatu. Ralph did not engage in overt "treating" or vote-buying practices favored by some of his rivals. Such practices are common knowledge around Port Vila, and make up many of the storian blong rod that circulated during the election campaign. ${ }^{7}$ One candidate was rumored to be giving a saucepan to each household that promised their vote to him; another was said to have found himself in a sticky situation when supporters discovered he had relocated the water pump promised to them to his cattle farm; and yet another was seen ducking off during a campaign event to withdraw large wads of cash from the automated teller, presumed to be for distribution to supporters. Ralph instead encouraged his supporters to enjoy the party atmosphere and perks associated with election time but to vote for him on the day. One of his campaign team members told me that his anti-bribery stance was so successful that a whole street was swayed to vote for him on the basis that he had refused to provide them with kava. This was read by them as validation of their decision-making powers-lack of patronage equated to lack of patronization.

Ralph's campaign also ran at a lower volume than most. A frequent sight and sound around town in the three weeks of campaigning is the 
convoy of trucks, buses, and cars, decorated with the candidate's colors, driving circuits of Port Vila, horns tooting and supporters cheering. Also, candidates will set up camp in a particular location (or series of venues), often for a whole weekend, running an almost twenty-four-hour party with food, kava, and music for supporters. These are institutionalized aspects of election time in Port Vila, and the bacchanalian possibilities appeal particularly to young people. However, such practices are viewed negatively by some: the accompanying level of disruption and rowdiness offends the burgeoning middle-class suburbanite sensibility, and the level of intrusion can offend community leaders and older people, who view them as "uninvited visitors." Counteracting these two lines of criticism, Ralph's campaign eschewed the convoy and kept loudspeaker use to a minimum. Chiefs and community leaders were approached for permission in advance of any visit, generally by a campaign committee member with connections to the community, and once the meeting was finished, the campaign team would leave.

Ralph's style of speaking did not subscribe to Marshall Sahlins's classic description of Melanesian big men as buffoonish "harangue-utan" in the way that some of the older political hands in town did (I963, 290). Instead, Ralph avoided high-volume hectoring in favor of a more measured delivery, starting with his reasons for standing as an independent, moving on to detailed accounts of political betrayals, misdemeanors, and corruption, and finishing with a meticulous outline of his policies. On average his speeches lasted for one and a half hours but could stretch to two hours. He engaged with those attending the meeting, drank kava with them, shook hands with them, and answered their questions honestly and in detail.

I would suggest that many of the characteristics that set Ralph's campaign apart contributed to a view of him as an appropriate leader-honesty, quietness, respect for community leadership and for the intelligence of supporters, asking permission before entering communities, and showing a willingness to engage, as evidenced by his marathon speeches. Conversely, we can also see some cracks emerging, the factors that threatened to set Ralph outside the acceptable parameters of leadership: he presented open and detailed criticism of his rivals, sometimes in their own communities, and appeared at a rival's meeting to ask a difficult question; he spoke the language of the educated, using legal terms and brandishing ombudsman's reports; and he positioned himself as a representative for Port Vila, in a town where "Vila identity" is not a commonly recognized concept- 
people wondered whom he would ultimately represent and benefit. Also problematic for some was the fact that Ralph is, in local idiom, a halfcaste. And what about his position on the decriminalization of marijuana? What about his connection to the annual music festival, Fest Napuanportrayed by one of his rivals as essentially an event designed to encourage young women to wear trousers-and, furthermore, his advocacy of legislating for increased participation by women in politics?

\section{Conclusion: What Made Ralph "Stret”?}

As suggested above, aspects of Ralph's campaign threatened to place him beyond the acceptable parameters of electability for a portion of the Port Vila constituency. So how were these grounds for rejecting his assertion of legitimate leadership qualities mitigated through the campaign? Two factors that appear to have played a part here are religion and history, especially the way they were tied together in publicly generated discourse. In Vanuatu, an opening and closing prayer provide the normal framing of any public event. Despite his background, Ralph is not a churchgoer, and he did not follow the standard formula in many of the public events he oversaw as director of the Vanuatu Cultural Centre. For this reason, I was quite surprised to see campaign team members giving opening and closing prayers at his meetings. Apparently his committee had been insistent from the start that prayer would play a part in all campaign proceedings. While dismissing another potential ground for criticism, the inclusion of prayer also enabled Ralph's campaigners to lend further moral weight and urgency to their requests for support. Ralph's rationality could be counterbalanced with appeals to the exercise of moral agency as granted by God in decisions about voting. Other potential sources of pressure in people's lives could be dismissed, as with the public assertion made by a campaign member that "the church isn't God; your chief isn't God ... only God has given you the power to choose good over evil, heaven over hell." 8 Thus voting could be portrayed as an abstracted and individuated process, combining the temporal morality of Ralph's policies with a spiritually oriented injunction to "do the right thing."

The inclusion of religion in the campaign also allowed Ralph's inclusion in a broader Christian framing of politics that gained popularity in the weeks leading up to the election. This discourse, circulated through letters to the editor, conversation in nakamals (kava bars), and public comment at candidate meetings, centered on the Old Testament figure Joshua and 
tied together the need for change with a respectful recognition of the history of parliamentary politics in Vanuatu. In the biblical account, Joshua was the figure who finally led the Israelites into the Promised Land, chosen by Moses as his successor to complete the task that Moses had begun. And so, in Vanuatu, Ralph and a number of other candidates were labeled the "Joshua Generation" and seen as those who could fully realize the aspirations of the independence movement. This provided an appropriate way to countenance support for a candidate such as Ralph and to "manage change" without conflict. Respectful acknowledgement of the implicitly "dead" first generation of postindependence politicians was allowed within this discourse, while providing an appropriate legitimating role to those who might otherwise be labeled as disrespectful upstarts.

Engaging in prayer and quoting from the Bible does not always look like politics. Indeed, the mix of temporality and spirituality observable at campaign meetings in Port Vila may well sit in tension with the idealized secular basis of Western liberal democracy. Unsurprisingly though, given the high level of Christian identification among ni-Vanuatu, direct use of religion in politics is not uncommon (see Eves 2008 and McDougall 2008 for examples from Papua New Guinea and Solomon Islands). In the 2008 election, a number of parties and candidates foregrounded Christianity as the basis for their political engagement, including the self-described "Official Candidate of Jesus Christ," Wendy Himford. However, such candidates do not attract a large degree of actual or anecdotal support. Annelin Eriksen's recent work with Pentecostal women's prayer groups in Port Vila suggests further ways in which Christianity and politics are entwined in Vanuatu. Her ethnography provides intriguing glimpses of women who meet to pray for the nation, targeting for intervention by the Holy Spirit areas such as electricity pricing, trade agreements, and corruption (Eriksen 2009a, I9I-I92). Eriksen has argued that such examples are indicative of a more generalized desire for reform of government and breaking with the past as a nation, which finds current expression through church activities (2009a, 2009b). Those involved in these exercises in spiritual intervention do not seek to become politicians; nonetheless they participate in the political process, using the power available to them to effect change. Yet, the discourse of the Joshua Generation does not fit clearly into either of these two camps, relying more on the assumption of a generalized knowledge of Christianity and on the acceptance of the legitimating power of parable. As such, it resonates with Bronwen Douglas's argument that Christianity provides a lens through which to assess and critique aspects of moder- 
nity in Vanuatu, politics included (2002). Thus, considerations and judgments regarding electoral legitimacy can come from unexpected quarters yet make sense when contextualized ethnographically and historically. This evidence demonstrates the need to consider politics as a non-discreet sphere of activity and to revise the implied aculturality of parliamentary politics produced through the problematization of "culture."

Through my presentation of his campaign, Ralph emerges as something of a mish-mash, entirely embodying neither the negative version of the Melanesian big-man politician nor the generic non-kin-reliant, nationalpolicy-oriented parliamentary candidate. However, I do not aim here to portray him as simply an anomaly; instead, my analysis indicates the need to consider electoral politics within the broader context of public culture in Vanuatu in order to understand how legitimacy is generated and also the networks involved in the production of policy and support. By tying together these different strands, we can gain a clearer picture of how Ralph came to be recognized as the "stret man" by a significant proportion of voters in Port Vila. We do not need to see him as atypical or novel to explain his success; he is embedded in extant institutions and practices, dependent on publicly generated discourses for acceptance, and judged by culturally defined measures of legitimacy. What he may more usefully represent, though, is a clear reminder that these things are not simply elements of a static, conservative, and problematic Melanesian style of politics.

I WOULD LIKE TO THANK the Vanuatu Cultural Council for granting me permission to carry out the research on which this essay is based. Thanks must also go to Ralph Regenvanu and members of his campaign committee for allowing me access to campaign events and for sharing their views on the 2008 election and political activity in Vanuatu with me. My understanding of these events benefited immensely from the generosity of a number of other interviewees who, while not named here, are acknowledged with much appreciation. Earlier versions of this paper were presented to the Pacific Research Cluster at the University of Otago and the Anthropology Seminar at the University of Canterbury and benefited from comments provided in those forums. Thanks also to John Taylor for general comments and Robert Early for linguistic expertise. Funding for this research was provided by the Department of Anthropology, Gender and Sociology at the University of Otago, and I am particularly grateful to Glen Summerhayes for his efforts in facilitating this. 


\section{Notes}

I Throughout this essay I have chosen to refer to Ralph by his first name, not because this is how I know him, but rather because this was how he was identified by the vast majority of people I spoke with, whether they knew him personally or not. The perhaps personal tone that this brings is not intended to lend an air of hagiography to my analysis; this essay should not be interpreted as an unequivocal endorsement of Ralph's campaign, policies, or actions as a member of Parliament. Unlike other politicians, he was not referred to by his last name, nor by any honorific. Since his election, he has been referred to as “MP Ralph,” but, again, he has not gained more detached or formalized terms of address in the way that many "old guard" politicians do. (See Lindstrom I997 for a discussion of the adoption and use of honorifics by politicians in Vanuatu.)

2 Ralph's decision to stand as an independent did not set him apart radically from other candidates. Vanuatu has a long history of high numbers of independent candidates, and 2008 featured a record high of 80 independents (out of a total of just over 300 candidates). Among these were people who had been passed over for official party endorsement but had been encouraged to stand by their own communities, as well as some who might be classified more as "fringe elements" or single-issue candidates. As in other years, prior to the election an "independent bloc" was mooted, of which Ralph was a part: a group of like-minded candidates, who agreed to a range of shared policy interests and committed to some degree of support for these once inside Parliament. While Ralph positioned himself as being against what he referred to as the natora (literally, heartwood or core of a tree trunk; in this context, a pejorative reference to the intransigent "political establishment") parties, he was not against political parties per se. He framed himself to me as one of several candidates "who just don't want anything to do with any parties at this stage." This suggests that his independent status was more a strategic move to gain his mandate from voters and use that to negotiate power in any relationships he chose to form. This conclusion is reinforced by his founding of the Land and Justice Party in late 2010.

3 A migration of the Daily Post website means that these comments are no longer available on-line (manuscript in author's possession).

4 Since his election, Ralph has managed to both engage with and circumvent more established parliamentary political practice. Continuing his activities connected to youth development, he initiated a youth micro-finance scheme and a scholarship program, both making use of the discretionary fund-“MP's allocation"-granted to members for use in their constituencies. He ended up in court, alongside Moana Carcasses, leader of the Green Confederation, following their intervention in a mass prison escape. He also started the Land and Justice Party, and has moved from opposition to government - twice so far-as part of broader maneuverings, fracturings, and coalition formations that have taken place. As 
of May 20II, he has moved rapidly through a number of ministerial portfolios: co-operatives and ni-Vanuatu business development (December 2010-February 20II); lands (February-March 20II); and, most recently, justice (initially April $20 \mathrm{I}$ and reinstated in mid-May $20 \mathrm{II}$ ).

5 This information came from approximately thirty short interviews I conducted with members of the public in Port Vila around election time. They were asked to describe what they felt was the appropriate manner for a candidate to conduct an election campaign.

6 In these posters, the prominence given to pictures of the candidates and associated symbols could be read as further evidence of the pervasiveness of personality. However, it must be remembered that the actual process of voting in Vanuatu differs from that followed in countries such as New Zealand and Australia. Given the relatively low levels of literacy, voters are presented with a booklet containing slips of paper that feature photos of the candidates, their party (or personal) logos, and their names, each on a specifically colored background. To vote, people detach the slip for their chosen candidate, put it into the ballot box, and dispose of the rest of the booklet. Thus visual aspects of presentation are an essential part of the campaigning process. For a comparative example from Pakistan on the role of campaign posters, see Malik nd.

7 Literally "stories of the road," these are the rumors that circulate in Port Vila, often passed on in buses, kava bars, the market, and through workmates.

8 Quotation from a speech by a campaign team member, Port Vila market house, 25 August 2008.

\section{References}

Australian Labor Party International Projects Unit

2008 The Political Parties and Groupings of Vanuatu. Port Vila: Pacific Institute for Public Policy.

Banerjee, Mukulika

2007 Sacred Elections. Economic and Political Weekly, 28 April: I556I 562 .

Comaroff, John L, and Jean Comaroff

I997 Postcolonial Politics and Discourses of Democracy in Southern

Diamond, Larry
Africa: An Anthropological Reflection on African Political Moderni- ties. Journal of Anthropological Research 53 (2): I23-I46.

I999 Developing Democracy: Toward Consolidation. Baltimore: The Johns Hopkins University Press.

Douglas, Bronwen

2002 Christian Citizens: Women and Negotiations of Modernity in Vanuatu. The Contemporary Pacific I4:I-38. 
Eriksen, Annelin

2009a "New Life": Pentecostalism as Social Critique in Vanuatu. Ethnos 74 (2): I75-I98.

2009b Healing the Nation: In Search of Unity through the Holy Spirit in

Eves, Richard Vanuatu. Social Analysis 53 (I): 67-8I.

2008 Cultivating Christian Civil Society: Fundamentalist Christianity, Politics and Governance in Papua New Guinea. State, Society and Governance in Melanesia Discussion Paper 2008/I. Canberra: The Australian National University.

Fry, Greg, and Tarcisius Tara Kabutaulaka, editors

2008 Intervention and State-building in the Pacific: The Legitimacy of "Co-operative Intervention." Manchester, UK: Manchester University Press.

Gellner, David N

2009 The Awkward Social Science? Anthropology on Schools, Elections and Revolution in Nepal. Journal of the Anthropological Society of Oxford NS I (2): I I 5-I 40.

Gershon, Ilana, and Janelle Taylor

2008 Introduction. In In Focus: Culture in the Spaces of No Culture. Special issue of American Anthropologist I IO (4): 4I7-42 I.

Lindstrom, Lamont

I997 Chiefs in Vanuatu Today. In Chiefs Today: Traditional Pacific Leadership and the Postcolonial State, edited by Lamont Lindstrom and Geoffrey White, 2I I-228. Stanford: Stanford University Press.

Malik, Nadeem

nd Informing or Campaigning? The Narrative of the State of Politics in

May, Ronald J Election Posters in Rural Pakistan. Manuscript in author's possession.

I982 Political Style in Modern Melanesia. In Melanesia: Beyond Diversity, edited by Ronald J May and Hank Nelson, 639-650. Canberra: Research School of Pacific Studies, The Australian National University.

McDougall, Debra

2008 Religious Institutions as Alternative Structures in Post-Conflict Solomon Islands? Cases from Western Province. State, Society and Governance in Melanesia Discussion Paper 2008/5. Canberra: The Australian National University.

McLeod, Abby

2008 Leadership Models in the Pacific. State, Society and Governance in Melanesia Discussion Paper 2008/6. Canberra: The Australian National University. 
Morgan, Michael

2003 Politik is Poison: The Politics of Memory among the Churches of Christ in Northern Vanuatu. PhD thesis, The Australian National University.

2005 Cultures of Dominance: Institutional and Cultural Influences on Parliamentary Politics in Melanesia. State, Society and Governance in Melanesia Discussion Paper 2005/2. Canberra: The Australian National University.

2008 Campaigns and Democracy in Melanesia: The 2008 Vanuatu Elections. Speech delivered at the Lowy Institute, I 7 September. Available at: http://www.lowyinstitute.org/Publication.asp?pid=892 [accessed 6 September 2010]

Reilly, Benjamin

2000 The Africanisation of the South Pacific. Australian Journal of International Affairs 54 (3): 26I-268.

2004 State Functioning and State Failure in the South Pacific. Australian Journal of International Affairs 58 (4): 479-493.

Rich, Roland, editor, with Luke Hambly and Michael G Morgan

2006 Political Parties in the Pacific Islands. Canberra: Pandanus Books.

Sahlins, Marshall D

I963 Poor Man, Rich Man, Big-Man, Chief: Political Types in Melanesia and Polynesia. Comparative Studies in Society and History 5 (3): 285-303.

Van Trease, Howard

2009 Vanuatu's 2008 Election: Difficulties of Government Formation in a Fractionalized Setting. State, Society and Governance in Melanesia Briefing Note 2009/I. Canberra: The Australian National University.

Van Trease, Howard, editor

I995 Melanesian Politics: Stael Blong Vanuatu. Christchurch: Macmillan Brown Centre for Pacific Studies; Suva: Institute of Pacific Studies.

\section{Abstract}

This dialogue piece provides an ethnographic account of the 2008 election campaign in Port Vila, Vanuatu. Focusing on the seemingly exceptional campaign and victory of Ralph Regenvanu, it is argued that current analytical perspectives on "Melanesian-style" politics misplace the role of culture in political activity in Vanuatu, treating it as a hindrance to the realization of an implicit ideal of “acultural” parliamentary politics. This serves to both dehistoricize and decontextualize the electoral participation of ni-Vanuatu. It is argued that ethnographic 
investigation of election campaigning produces a more nuanced picture of both continuous and novel aspects of political engagement. Particular attention is given to the production of policy over time, and the ways in which leadership is manifested and judged in the context of elections. This allows us to understand Ralph's success as embedded within ongoing civil society politics in Vanuatu and dependent on public discourses regarding the legitimacy of leadership, rather than viewing it as an anomalous victory over "culture."

KEYWORDS: Vanuatu, Ralph Regenvanu, elections, leadership, electoral participation, campaigning, culture 